\title{
Grupo de Atividade Externa: a Ampliação do Repertório Sociocultural como Possibilidade Transformadora na Assistência Psiquiátrica
}

\author{
Figueiredo, Maitá Seixas de; Oliveira, Lucieide P. da Silva \\ Instituto de Psiquiatria HCFMUSP — maita.figueiredo@hc.fm.usp.br
}

\begin{abstract}
Introdução a Política Nacional de Saúde Mental propõe modelos assistenciais articulados, pautados na inserção familiar e social dos sujeitos. Prevê tratamentos dignos e humanizados que substituam, progressivamente, os modelos asilares preponderantes na história da psiquiatria. a Atividade Externa acontece em um serviço semi-intensivo que compõe essa rede de equipamentos assistenciais em psiquiatria. Esse serviço tem como paradigma central a compreensão biopsicossocial dos sujeitos e o trabalho se efetiva em ambiente propicio à participação, por meio de atividades grupais, vivências transformadoras e articulação intensiva entre a equipe. Objetivos o grupo objetiva a realização de atividades culturais e de lazer pela cidade, no intuito de fortalecer a autonomia, despertar interesses, estimular a iniciativa, o pragmatismo e ampliar o repertório sociocultural de seus participantes. Métodos a Atividade Externa acontece semanalmente, coordenada por uma Assistente Social e uma Auxiliar de Enfermagem. Os pacientes são previamente triados com base na demanda de tratamento e no vínculo estabelecido. na primeira semana de cada mês há a programação, onde todos trazem sugestões de locais a serem visitados nas semanas seguintes. com base na viabilidade (custo, distância, disponibilidade de agendamento) há uma votação e decisão. Esse processo é anotado pelos pacientes em caderno específico do grupo. nas saídas, tanto as profissionais quanto os residentes e aprimorandos, não devem usar jalecos ou crachás, no intuito de facilitar a formação e pertencimento grupal. Sempre são utilizados transportes públicos, o que compõe o exercício de cidadania proposto. Durante toda a atividade os pacientes são incentivados a conduzir a comunicação e tomar as decisões necessárias. o mesmo acontece na resolução dos conflitos e imprevistos. É no momento da próxima programação que as saídas são avaliadas e discutidas por todos. Tanto o processo do grupo, quanto as percepções singulares de cada paciente, são compartilhados em reunião de equipe e evoluídos nos prontuários. Resultados: o grupo tem tido especial importância no processo de pertencimento e apropriação dos espaços comunitários pelos sujeitos envolvidos. Acompanhamos o desenvolvimento de habilidades e recursos na interação social mais ampla, o que, por vezes, é refletido positivamente na sintomatologia. o protagonismo e empenho dos participantes no que se refere ao grupo é outro parâmetro que nos leva a avaliá-lo positivamente em seus objetivos. Conclusões: a experiência no grupo nos faz concluir que espaços de tratamento extramuros devam ser partes integrantes das propostas de Reabilitação Psicossocial. Evitando manejos paternalistas, pensamos que, proporcionar tais vivências, seja importante na aceitação social de sujeitos historicamente estigmatizados e discriminados. Dessa forma, a Atividade Externa existe como espaço transformador e humanizador, não só dos pacientes, mas dos profissionais envolvidos e da sociedade que nos recebe.
\end{abstract}

Figueiredo, Maitá Seixas de; Oliveira, Lucieide P. da Silva. Grupo de Atividade Externa: a Ampliação do Repertório Sociocultural como Possibilidade Transformadora na Assistência Psiquiátrica. In: Anais do Congresso Internacional de Humanidades \& Humanização em Saúde [= Blucher Medical Proceedings, num.2, vol.1]. São Paulo: Editora Blucher, 2014. ISSN 2357-7282 DOI 10.5151/medpro-cihhs-10549 